ACTA MYCOLOGICA

Vol. 48 (2): 263-277

2013
Dedicated to Professor Maria Ławrynowicz on the occasion of the 45th anniversary of her scientific activity

DOI: $10.5586 /$ am.2013.029

\title{
Mycobiota of rape seeds in Romania. I. Identification of mycobiota associated with rape seeds from different areas of Romania
}

\author{
TATIANA-EUGENIA ŞESAN ${ }^{1}$ and OCTAVIAN GROZA ${ }^{2}$
}

\author{
${ }^{1}$ Department of Botany and Microbiology, Biology Faculty \\ University of Bucharest, 1-3 Portocalelor Alley, R-060101 Bucharest 35, tatianasesan@yahoo.com \\ ${ }^{2}$ Central Laboratory of Testing Quality of Seeds and Propagative Materials \\ 10 Sandu Aldea Alley, R-012065 Bucharest 32
}

Şesan T.-E., Groza O.: Mycobiota of rape seeds in Romania. I. Identification of mycobiota associated with rape seeds from different areas of Romania. Acta Mycol. 48 (2): 263-277, 2013.

The spectrum of fungal diversity associated with rape seeds belonging to 33 cultivars (Alaska, Astrada, Astrid, Atlantic, Betty, Champlein, Chayenne, Dexter, Digger, Elvis, Eurowest, Finesse, Herkules, Hydromel, Hydromel-MA, Ladoga, Manitoba, Masa Rom, Milena, Mohican, Montego, Nectar, Ontario, Orkan, Perla (4 lots), Remy, Robust, Rodeo, Saphir, Tiger, Tiger CBC Lot ROM06-121-110, Triangle, Valesca, Vectra) and 2 hybrids (H90-20-83, H-90-21-83) has been established by samples' macroscopical and microscopical analizying, during 2006-2008, for the first time in Romania. The Ulster method on malt-agar and PDA culture media has been used, evaluating the percentage of fungal taxons present on/ in rape seeds. The most important pathogenic fungi identified were: Sclerotinia sclerotiorum (Lib.) de Bary, Botrytis cinerea Pers., Rhizoctonia solani Kühn, Alternaria brassicae (Berk.) Sacc., A. brassicicola (Schwein.) Wiltshire and Fusarium spp. Also, a large quantities of some saprophytic fungi, as Alternaria, Cladosporium, Aspergillus, Penicillium, Rhizopus have been recorded. These ones have been affected the health condition of rape seeds, suppressing their germination and other vital phenomena. Among potential antagonistic fungi the followiung genera have been isolated: Chaetomium (0-4\%), Trichoderma (0-10\%), Aspergillus (0-14\%), Penicillium (0-100\%). Some correlations and comparisons have been established between fungal diversity, their provenience, cultivars, culture media (Malt-Agar/MA, Potato-DextroseAgar/PDA) used. It has been evaluated the behaviour of rape cultivars and hybrids towards the main rape seed pathogens.

Key words: rape, mycobiota, seed-borne fungi, potential antagonistic fungi 


\section{INTRODUCTION}

Rape is in Romania at present an extending crop in comparaison with the years 20012005, when its area was in a significant decreasing. The largest area of rape crop has been recorded until now in 2010, the increasing of its surface starting since 2007 (Tab. 1). The highest values of the rape yields (569.6-943.0 thousands tones/ha) have been obtained during 2008-2010 and the lowest one (8.1-98.7 thousands tones/ha) during 2002-2004.

Regarding the average yield evaluated in $\mathrm{kg}$ rape seeds/ha, the highest seed production (1984 kg/ha) was recorded in 2004, followed by the values of $1357-1844 \mathrm{~kg} /$ ha between 2005-2010, with an exception (991 kg/ha) in 2007.

Table 1

Dynamics of rape crop areas and yields during 2001-2010 in Romania (after the Statistical Yearbooks of Romania, 2007-2011)

\begin{tabular}{|c|c|c|c|}
\hline Year & $\begin{array}{c}\text { Crop area } \\
\text { (thousands ha) }\end{array}$ & $\begin{array}{c}\text { Yield } \\
\text { (thousands tones/ha) }\end{array}$ & $\begin{array}{c}\text { Average yield } \\
\text { (kg/ha) }\end{array}$ \\
\hline 2001 & 82.4 & 101.0 & 1235 \\
\hline 2002 & 74.6 & 35.9 & 481 \\
\hline 2003 & 17.1 & 8.1 & 473 \\
\hline 2004 & 49.7 & 98.7 & 1984 \\
\hline 2005 & 87.8 & 147.6 & 1681 \\
\hline 2006 & 110.1 & 175.1 & 1590 \\
\hline 2007 & 364.9 & 361.5 & 991 \\
\hline 2008 & 365.0 & 673.0 & 1844 \\
\hline 2009 & 419.0 & 569.6 & 1357 \\
\hline 2010 & 537.3 & 943.0 & 1755 \\
\hline
\end{tabular}

the lowest values

In order to obtain a constant valuable rape yield it has to be applied in the crop technology the suitable agrotechnological and protection methods, providing a healthy crop developped from high quality seeds, free of seed-borne pathogens, with a high germinative faculty. Also, in the frame of the sustainable agriculture concept, it has to be substitute, as much as possible, the chemicals with the ecological, non-chemical products or with different other alternative non-polluting protection means (Baicu, Săvescu 1986; Hălmăjan et al. 2006).

These objectives have been followed during our researches, starting with an approach on endo- and epiphytic mycobiota of rape seeds belonging to various cultivars from different pedoclimatic zones of Romania.

In general, there are a few researches on seed pathology in Romania, like books of Hulea et al. (1973) or Raicu and Baciu (1978). Also, no papers referring to the mycobiota of rape seeds in Romania have been presented, but not published in extenso until now (Tabuc, Ştefan 2003; Şesan, Groza 2007; Şesan 2008). This paper is the first published contribution in the field of seed-pathology of rape in order to have an evaluation of rape seed-borne fungi/mycobiota as a reference point for obtaining a healthy and efficient, productive rape crop.

The objective of this study has been the investigation and evaluation the rape seed healthiness and detection of potential active antagonistic fungi against the main rape phytopathogens in order to be used in the future in their biocontrol. 


\section{MATERIAL AND METHODS}

As a biological material a number of 39 rape seed samples have been analyzed: 8 samples from the Central Laboratory of Testing Quality of Seeds and Propagative Materials (CLTQSPM) Bucharest (South of Romania), 7 from the Agricultural Experimental Research-Development Station (AERDS) Secuieni, Neamț district (North-Est of Romania), 24 from the Agricultural Experimental Research-Development Station (AERDS) Caracal, Olt district (South of Romania). These samples belong to 33 rape cultivars (Alaska, Astrada, Astrid, Atlantic, Betty, Champlein, Chayenne, Dexter, Digger, Elvis, Eurowest, Finesse, Herkules, Hydromel, Hydromel-MA, Ladoga, Manitoba, Masa Rom, Milena, Mohican, Montego, Nectar, Ontario, Orkan, Perla (4 lots), Remy, Robust, Rodeo, Saphir, Tiger, Tiger CBC Lot ROM06-121-110, Triangle, Valesca, Vectra) and 2 hybrids (H-90-20-83, H-90-2183), from the seed yields of 2006 and 2007 years.

Methods used for the identification of mycobiota associated with rape seeds were: macroscopical analyze, optical microscopy (microscope Olympus CX 41 from Japan, with a digital soft camera control panel SP-350), wet chamber and Ulster methods, on two culture media: Malt-Agar (MA) and Potato - Dextrose - Agar (PDA) (Neergaard 1979; Musket, Malone 1997; Machado et al. 2002).

The evaluation of the data has been done by the frequency $(F)$ of seed- and soilborne fungi associated with the rape seed samples (Tab. 2, Figs 1-3).

Fungal nomenclature has followed Index Fungorum (http://www.indexfungorum. org) and Dictionary of the Fungi (Kirk et al. 2008).

\section{RESULTS AND DISCUSSION}

The performed results on identification of mycobiota associated with rape seeds from different areas of Romania are presented in the Table 2, Figs. 1-3 and Plates 1-5.

The most important seed-borne phytopathogens for the rape seeds are: Sclerotinia sclerotiorum (Lib.) de Bary, Botrytis cinerea Pers., Rhizoctonia solani Kühn, Alternaria brassicae (Berk.) Sacc., A. brassicicola (Schwein.) Wiltshire, Fusarium spp.

Among these, the first significant phytopathogens (S. sclerotiorum, B. cinerea) haven't been identified in all analyzed seed samples from the yields of 2006-2007 years. Absence of these seed-borne fungi was correlated with the crop rotation, avoiding sensitive plants (sunflower, soybean, carot, potato) to these pathogens in the same asolament and especially with the very dry climatic conditions during 20062007.

It has been identified in only one sample, cv. Eurowest, the fungus Rhizoctonia solani Kühn, with a low frequency of $1 \%$.

Among soil-borne pathogens, there were identified Fusarium spp., with a high frequency until $51 \%$, and average limits between 0.4 until $10.25 \%$, present in $62.5 \%$ of seed samples. The highest level of Fusarium spp. has been detected on the Masa Rom cv. (51\%), followed by Hydromel-MA cv. (26\%), Elvis (22\%) and then by the hybrid H-90-21-83 (12\%). The lowest occurence of Fusarium spp. (F = 1\%) has been detected for the cultivars: Tiger, Dexter, Finesse and Herkules. 

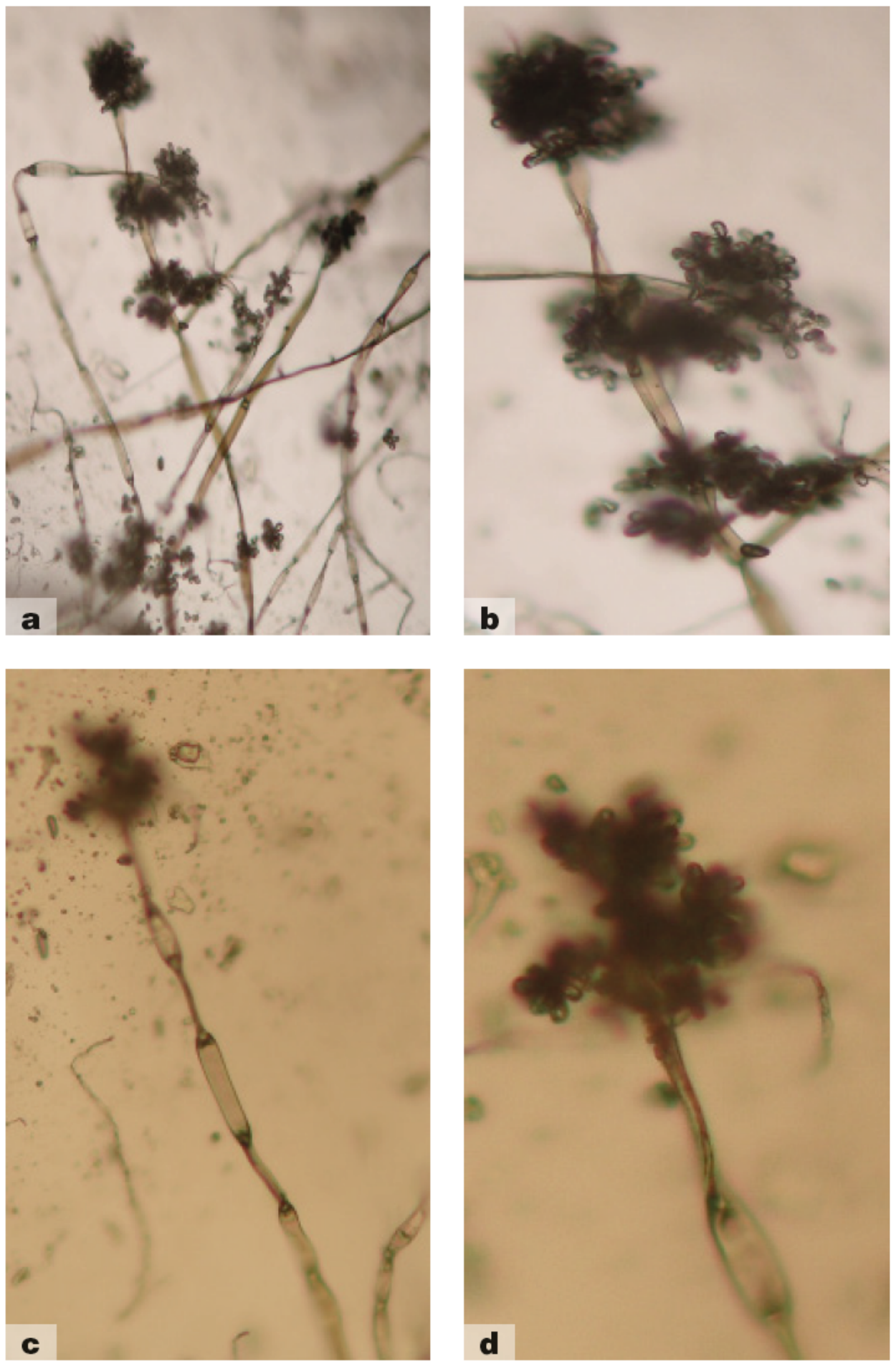

Plate 1. Botrytis cinerea: conidiophores and conidia; a-c-20x; b-d - $40 \mathrm{x}$. 

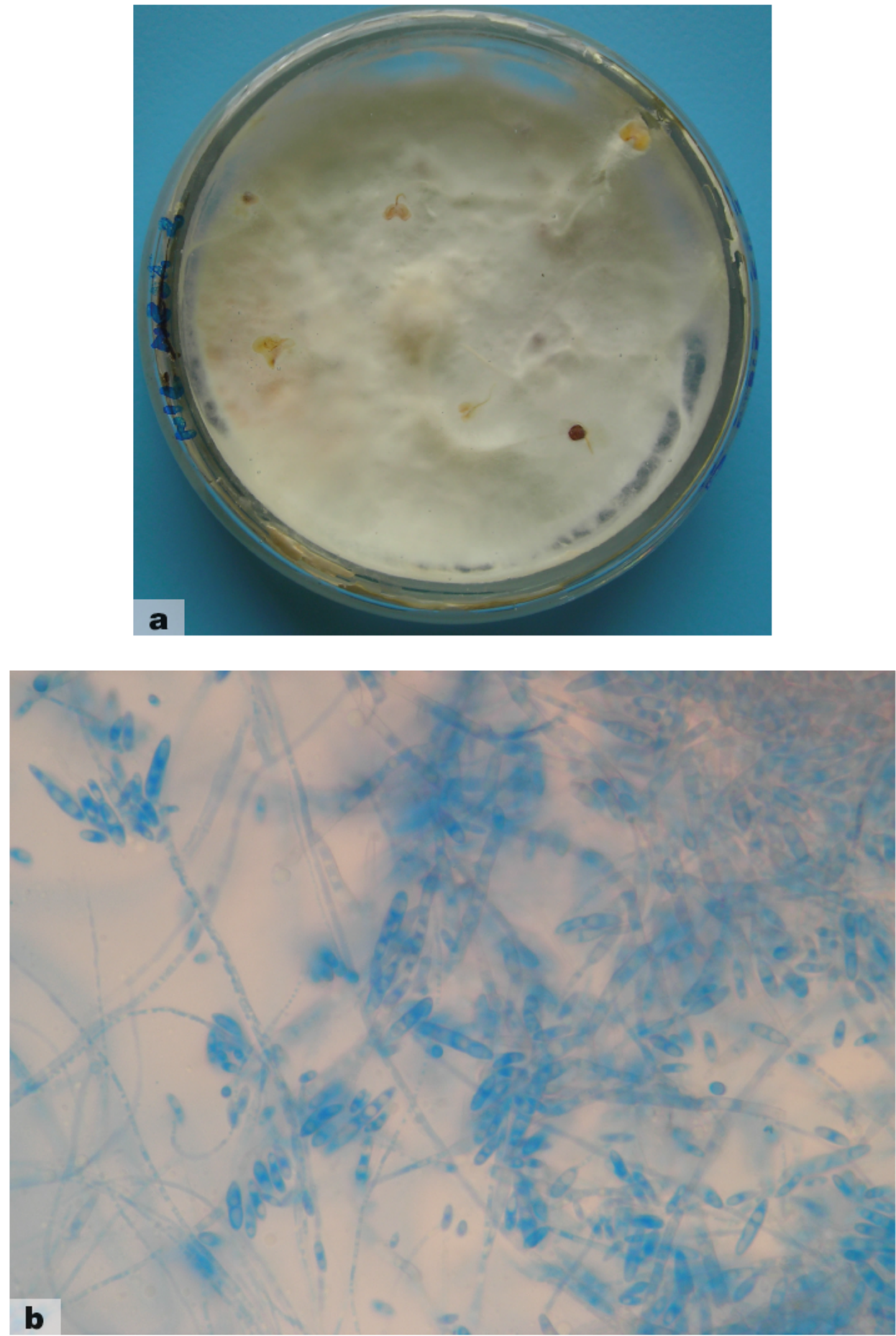

Plate 2. Fusarium spp.: a - Petri plate prepared by Ulster method for rape seed-borne mycobiota identification; $\mathrm{b}$ - conidiophores and conidia, coloured with bleau cotton (40 $\mathrm{x})$. 

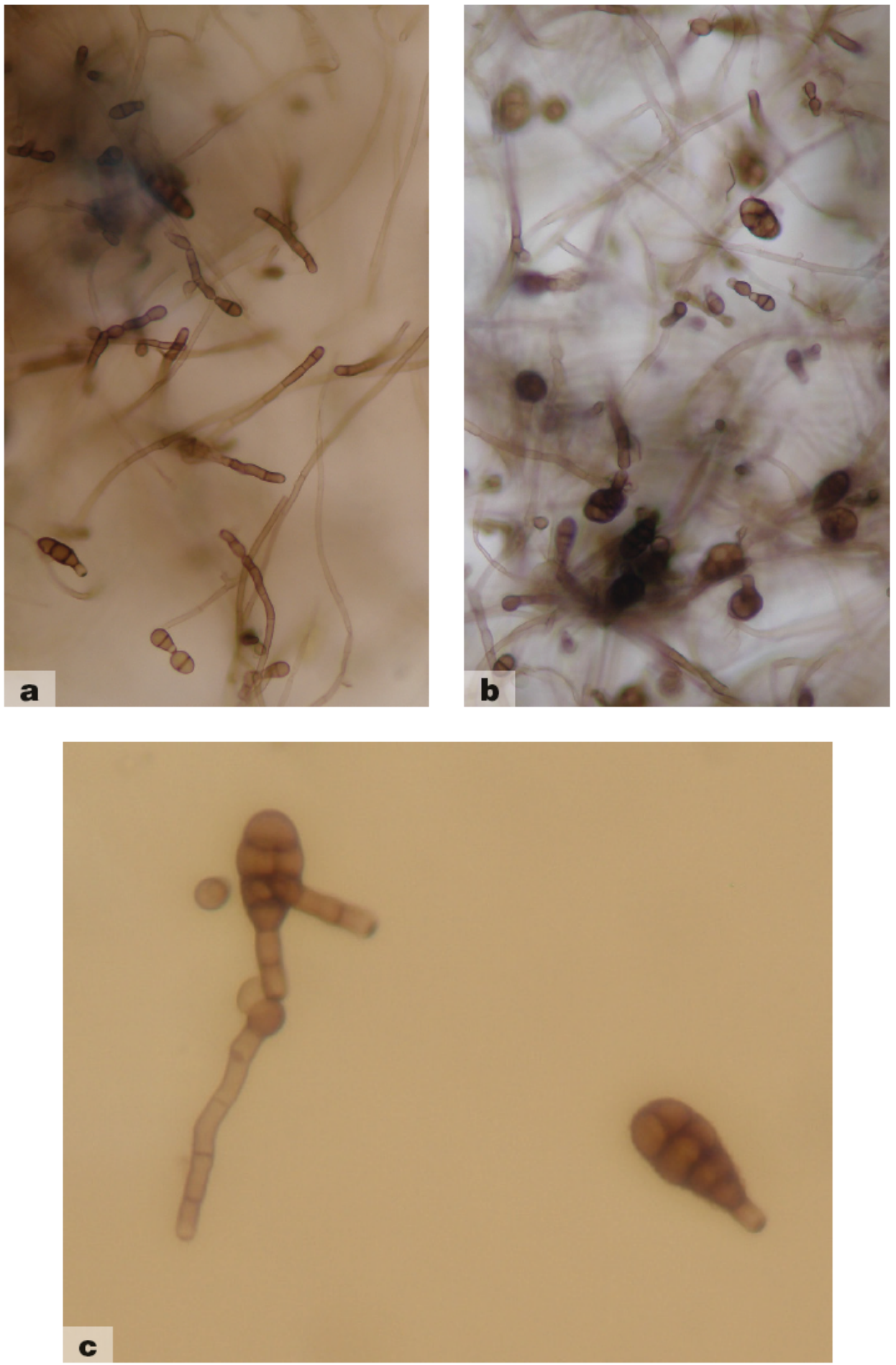

Plate 3. Alternaria tenuis: a-b - conidiophores and conidia (20x); c-conidia (40x). 
Mycobiota of rape seeds in Romania. I.
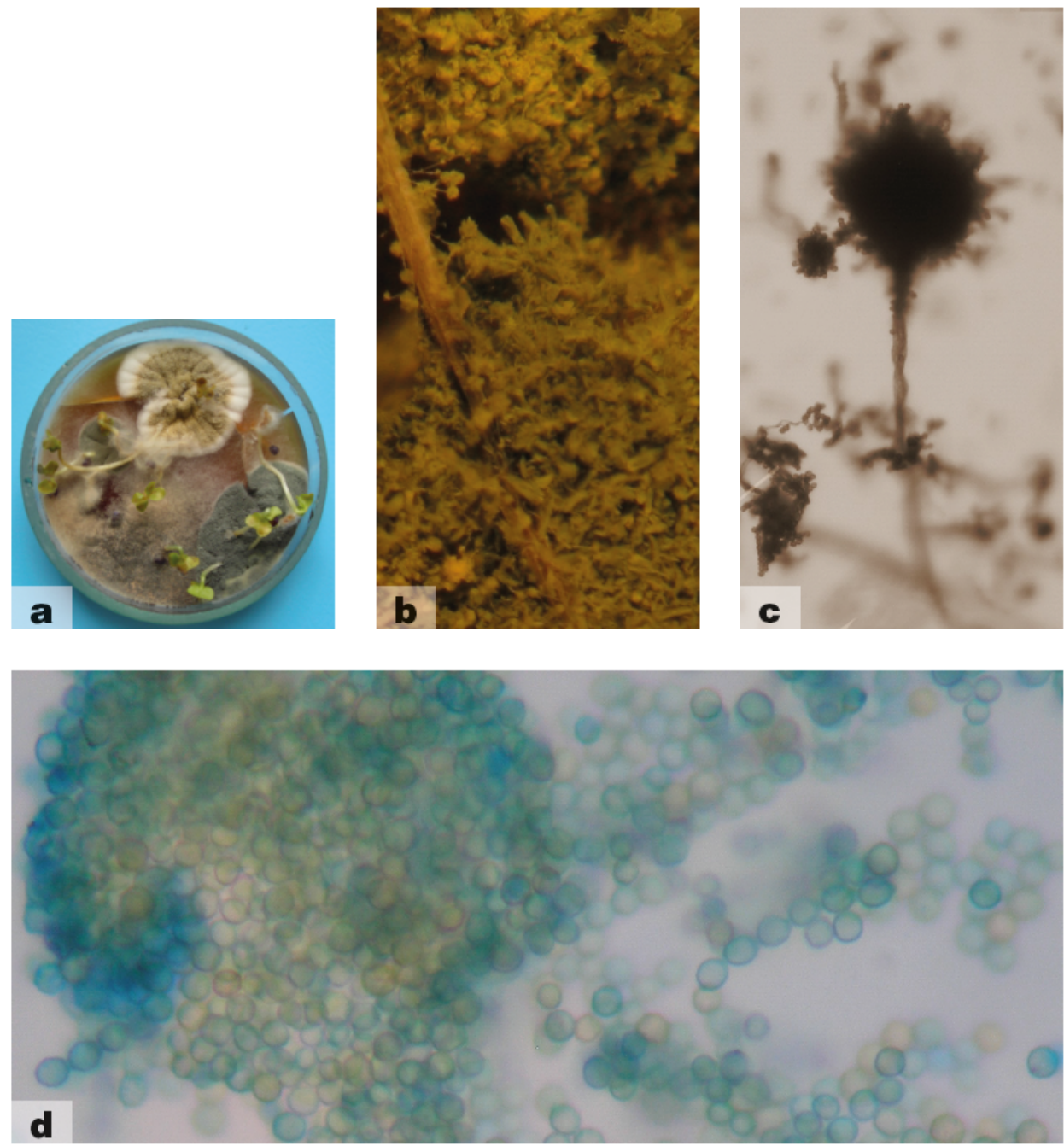

Plate 4. Aspergillus ochraceus: $a$ - colony on PDA Petri plate; $b-A$. ochraceus - image under stereomicroscop with conidiophores and the conidia-forming tips; $\mathrm{c}$ - conidiophore and conidia $(40 \mathrm{x}) ; \mathrm{d}$ - conidia $(60 \mathrm{x})$. 

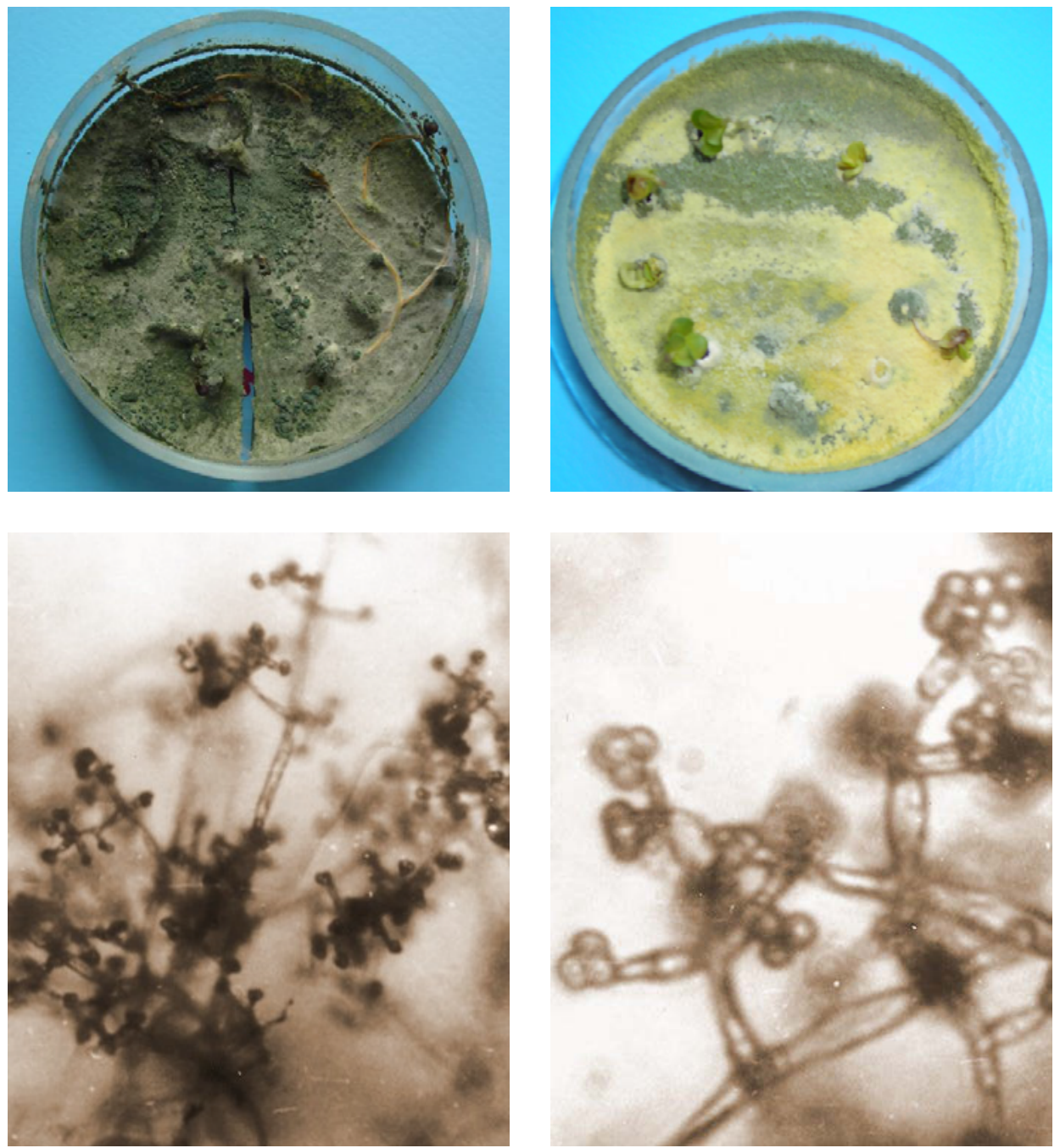

Plate 5. Trichoderma spp. Isolated from rape seeds: a-b - Petri plates prepared by Ulster method, where Trichoderma spp. has developed; c - conidiophores and conidia (10 x); d - idem $(20 \mathrm{x})$. 


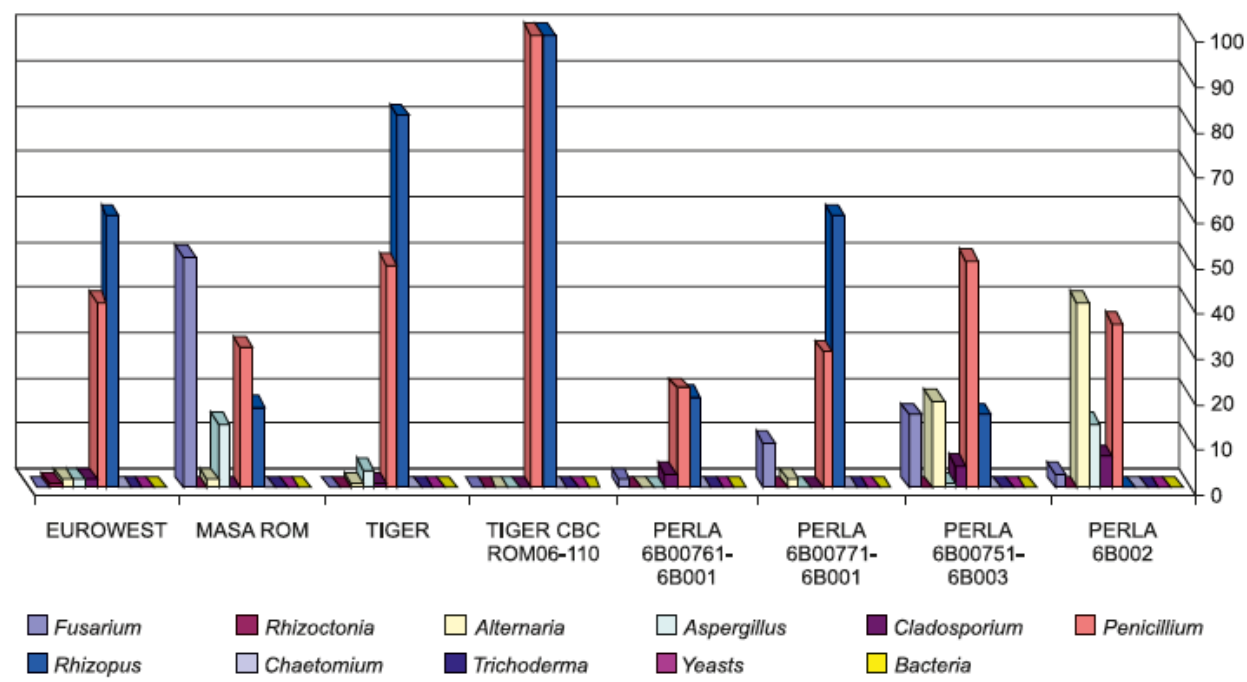

Fig. 1. Mycobiota frequency (\%) from rape seeds on Malt-Agar (MA) medium (2007).

In $75 \%$ of the analizyed seed samples, there were identified species of Alternaria, with frequency until the highest value of $66 \%$, and average limits between 6.3 until $15 \%$. Among these species, the predominant one was $A$. alternata Fr.: Fr. Keissler (A. tenuis Nees). Among seed samples, the highest fungal presence of Alternaria spp. has been recorded for the Milena cv. (66\%), followed by the hybrid H-90-21-83 and Perla cv. - Lot 6B002 (44-41\%), and then by the cultivars Alaska (34\%), HydromelMA (34\%) and Robust (26\%). The lowest percent of Alternaria has been recorded on the Tiger cv. (1\%).

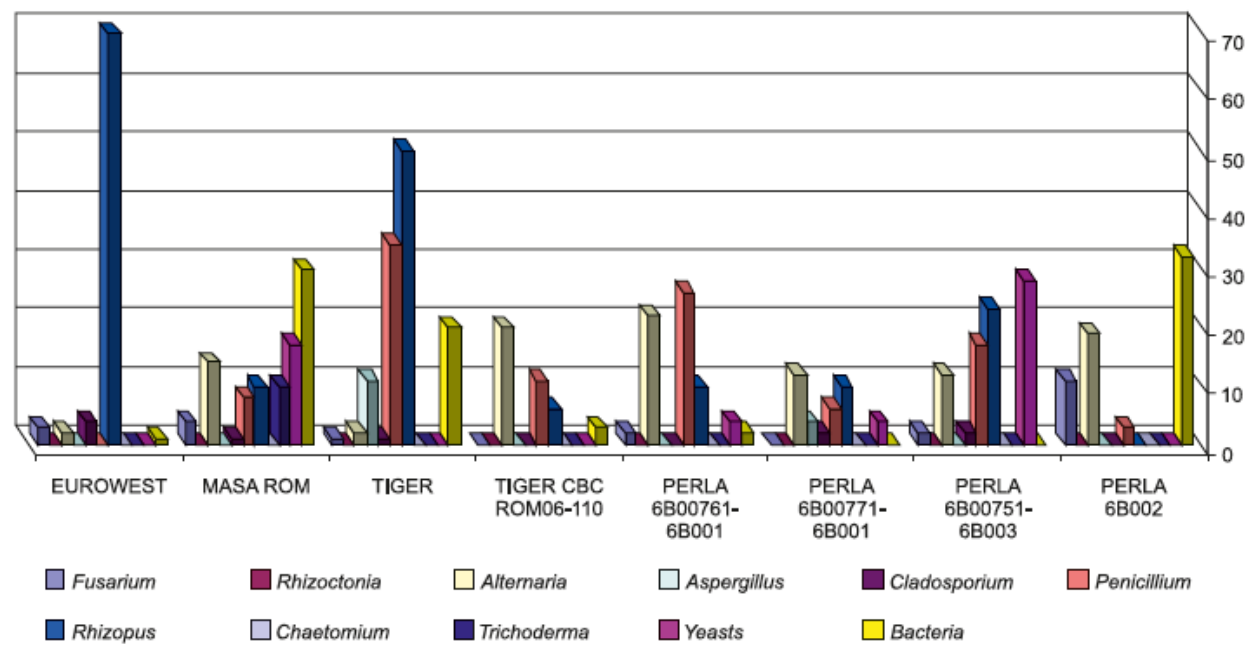

Fig. 2. Mycobiota frequency (\%) from rape seeds on Potato Dextrose Agar (PDA) medium (2007). 


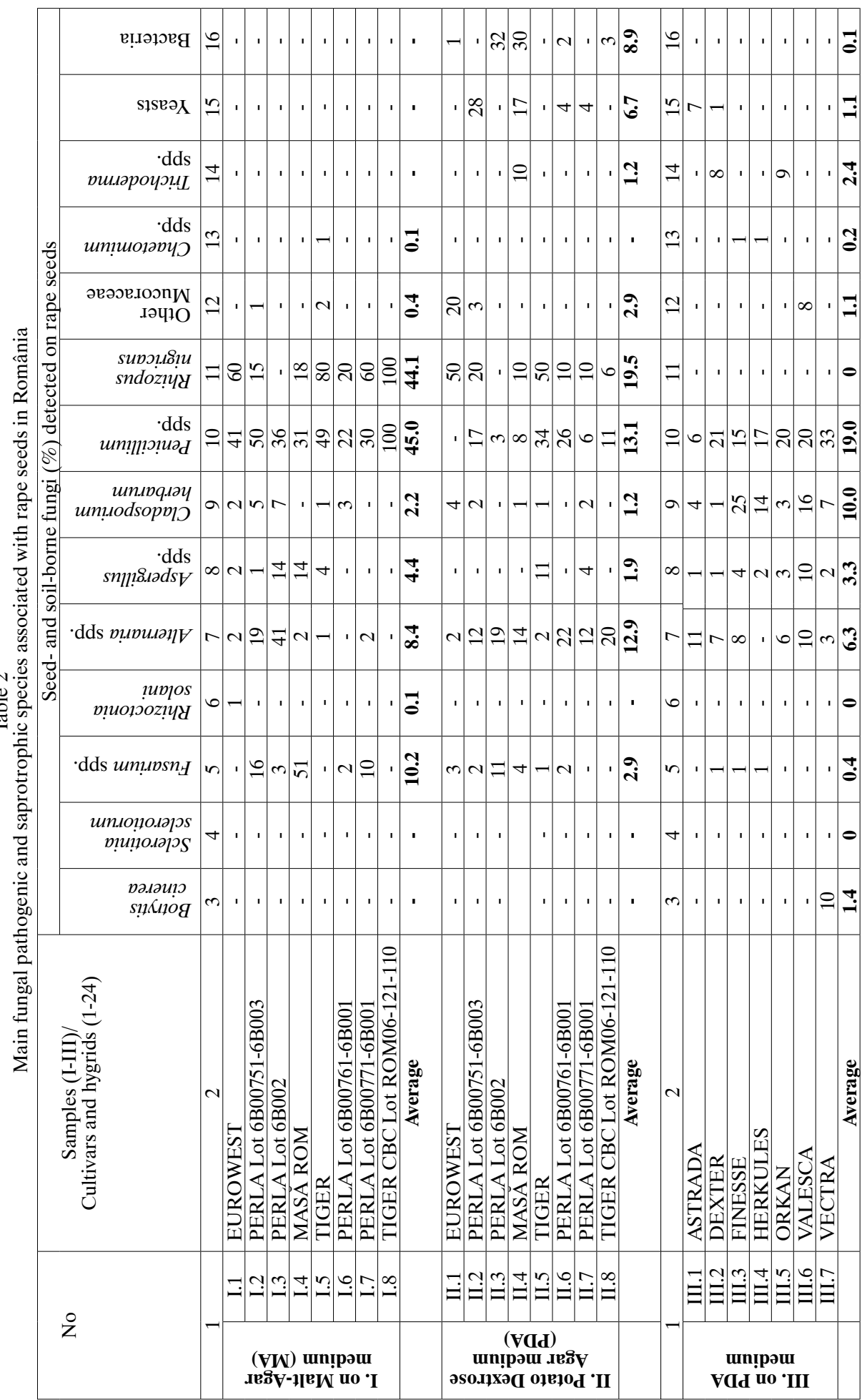




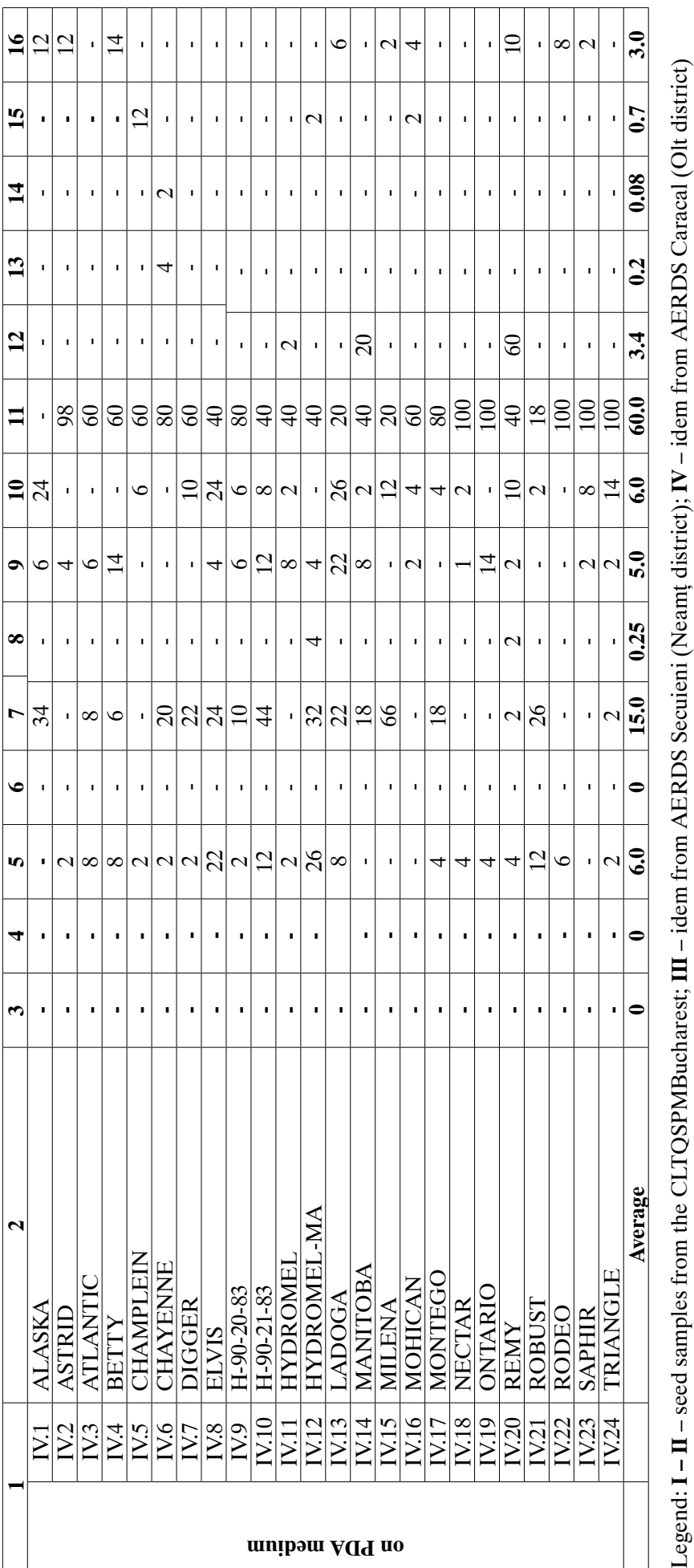




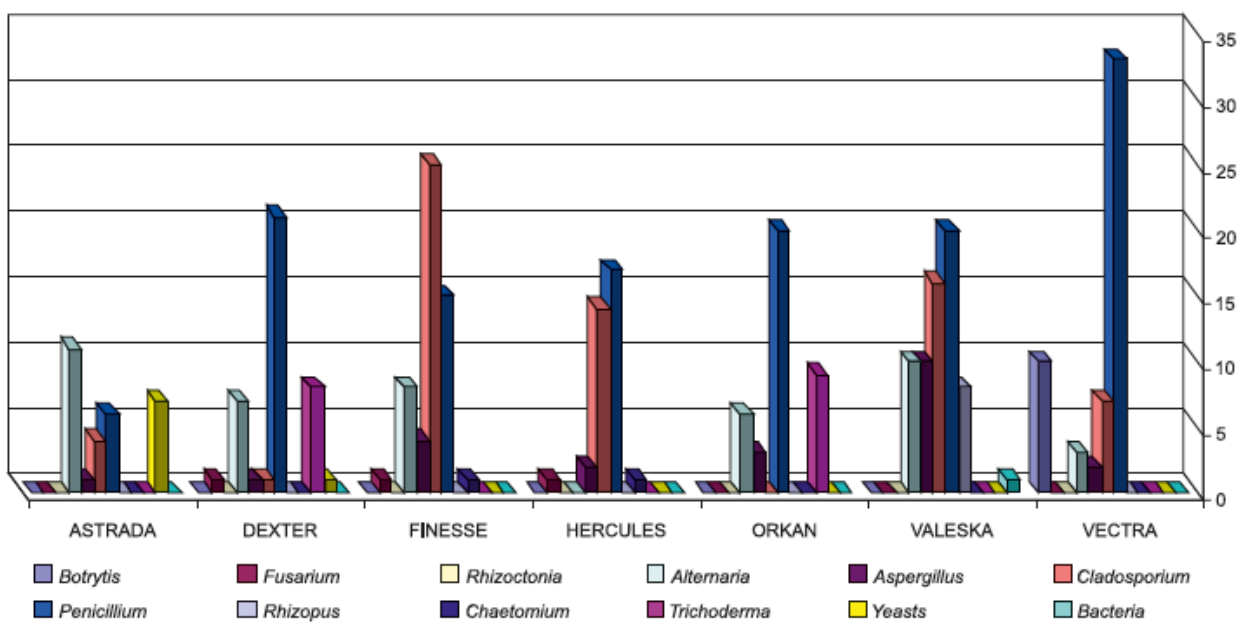

Fig. 3. Mycobiota frequency (\%) on rape seeds from AERDS Secuieni - Neamt District (2008).

In almost all seed samples, epiphytic fungi have been identified. These ones, by their presence in such high level, increase the negative effects produced by phytopathogenic ones. These species were: Aspergillus spp. ( $\mathrm{F}=0-14 \%$, mean limits between 0.25-4.4\%), Cladosporium herbarum (Pers.) Link : S. F. Gray ( $\mathrm{F}=0-25 \%$, mean limits between 1.2-10.0\%), Penicillium spp. ( $\mathrm{F}=0-100 \%$, mean limits 6-45\%), Rhizopus stolonifer (Ehrenb.: Fr.) Lind. ( $\mathrm{F}=0-100 \%$, mean limits 19-60\%) and other fungi from Mucoraceae family $(\mathrm{F}=0-60 \%$, mean limits between $0.4-3.4 \%)$.

Among the potential antagonistic fungi, there were recorded from rape seeds: Chaetomium spp. ( $\mathrm{F}=0-4 \%$, average limits between $0.1-0.2 \%)$, Trichoderma spp. (F $=0-10 \%$, average limits $0.08-2.4 \%)$, and Aspergillus $(\mathrm{F}=0-14 \%$, average limits between $0.25-4.4 \%$ ), Penicillium ( $\mathrm{F}=0-100 \%$, average limits between 6-45\%), already mentioned up, a.o.

Comparing the results performed on the two culture media, MA and PDA, it is evident that rape seed-borne fungi have grown better on MA and less on PDA (Tab. 2, I-II; Tab. 3).

Table 3

Comparaison between occurrence of rape seed-borne mycobiota developped by Ulster method on MA and PDA culture media

\begin{tabular}{|l|c|c|}
\hline \multirow{2}{*}{ Fungi } & \multicolumn{2}{|c|}{ Limits of frequency (mean) \% } \\
\cline { 2 - 3 } & MA & CGA \\
\hline Alternaria spp. & $1-41(8.4)$ & $4-11(1.9)$ \\
\hline Aspergillus spp. & $1-14(4.4)$ & $1-4(1.2)$ \\
\hline Cladosporium herbarum & $1-7(2.2)$ & $1-11(2.9)$ \\
\hline Fusarium spp. & $2-51(10.2)$ & $3-34(13.1)$ \\
\hline Penicillium spp. & $22-100(45.0)$ & $6-50(19.5)$ \\
\hline Rhizopus stolonifer & $15-100(44.1)$ & - \\
\hline Rhizoctonia solani & 1 & $0-10(0.08-2.4)$ \\
\hline Trichoderma spp. & - & \\
\hline
\end{tabular}


In the performed investigations, Rhizoctonia solani have been identified on MA culture medium and it has not been recorded in our tests on the PDA culture medium. Also, in the Petri plates, on PDA medium, Trichoderma spp. have been identified. On the same culture medium (PDA) yeasts and bacteria associated with rape seeds presented a good development (Tab. 2, I-II) in comparaison with MA medium.

These results explain why ISTA recommends Ulster method on the MA culture medium as a generalized standard method for seed pathology/ phytosanitary tests for the majority of cultivated plants (Malone, Muskett 1997; Machado et al. 2002).

Our results concerning the most important fungal phytopathogens of rape seeds - Sclerotinia sclerotiorum (Lib.) de Bary, Botrytis cinerea Pers., Rhizoctonia solani, Alternaria spp., especially A. brassicae (Berk.) Sacc., A. brassicicola (Schwein.) Wiltshire and Fusarium spp. - are similar with the results of other European scientistis as Polish ones (Dakowska, Jędryczka 2003; Jędryczka et al. 2002, 2003; Sadowski et al. 2002a, 2002b). In addition, these results confirm the significance of these rape pathogens not only in Europe, but in the world, too (Agrios 2005; Saharagan et al. 2005; Cnola, Canada 2006).

\section{CONCLUSIONS}

1. The spectrum of fungal diversity associated with 39 rape seed samples belonging to 33 cultivars (Alaska, Astrada, Astrid, Atlantic, Betty, Champlein, Chayenne, Dexter, Digger, Elvis, Eurowest, Finesse, Herkules, Hydromel, Hydromel-MA, Ladoga, Manitoba, Masa Rom, Milena, Mohican, Montego, Nectar, Ontario, Orkan, Perla (4 lots), Remy, Robust, Rodeo, Saphir, Tiger, Tiger CBC Lot ROM06121-110, Triangle, Valesca, Vectra) and 2 hybrids (H-90-20-83, H-90-21-83) has been established by samples' macroscopical and microscopical analizes using Ulster method, during 2006-2008, in Romania.

2. The most important detected seed-borne phytopathogens for the rape seeds are: Botrytis cinerea Pers. ( $\mathrm{F}=10 \%$, only on the Vectra cv.), Rhizoctonia solani Kühn ( $\mathrm{F}=1 \%$, only on the Eurowest cv.), Alternaria spp., among them Alternaria brassicae (Berk.) Sacc., A. brassicicola (Schwein.) Wiltshire (F = 0-66\%) and Fusarium spp. $(\mathrm{F}=0-51 \%)$.

3. Saprophytic seed-borne fungi recorded with the highest frequency on rape samples have been: Cladosporium herbarum ( $\mathrm{F}=0-25 \%)$, Aspergillus spp. $(0-14 \%)$, Penicillium spp. (0-100\%), Rhizopus stolonifer (0-100\%), their presence affecting the seeds health status, mainly their germination faculty.

4. A strong contamination of rape seed samples from the South of Romania with Rhizopus stolonifer represents a risk factor in obtaining a healthy and highly productive rape crop.

5. Among the potential antagonistic fungi associated with rape seeds the following species have been detected: Chaetomium spp. (0-4\%), Trichoderma spp. (0-10\%), Aspergillus (0-14\%), Penicillium (0-100\%) a.o. This category of micromyceta are important in the selection of actives isolates for using them in biocontrol of phytopathogens. 
6. Investigations performed on rape seed allow to evaluate the behaviour of 37 cultivars and 2 hybrids of rape to the main seed- and soil-borne fungi. It has been found 13 rape cultivars (Eurowest, Tiger CBC Lot ROM06-121-110, Astrada, Orkan, Valesca, Vectra, Alaska, Manitoba, Milena, Mohican, Saphir, Triangle) as resistant to Fusarium spp., 11 cultivars (Perla Lot 6B00761-6B001, Tiger CBC Lot ROM06-121-110, Herkules, Astrid, Champlein, Hydromel, Mohican, Nectar, Ontario, Rodeo, Saphir) resistant to Alternaria spp. and 9 cultivars (Astrada, Dexter, Finesse, Herkules, Orkan, Valesca, Vectra, Perla Lot 6B002, Alaska) resistant to Rhizopus stolonifer.

On the other hand, some cultivars proved sensitivity to the main seed- and soilborne fungi: 3 sensitive cultivars (Masa Rom., Hydromel-MA, Elvis) to Fusarium spp., 4 cultivars (Milena, Perla Lot 6B00751-6B003, Alaska, Robust) and 1 hybrid (H-90-21-83) to Alternaria spp., and 6 cultivars (Ontario, Tiger CBC Lot ROM06121-110, Nectar, Rodeo, Saphir, Triangle) to $R$. stolonifer. These data are very useful to the practice for selection of cultivars/hybrids in order to obtain a healthy and productive rape crop.

Acknowledgements. The authors are very grateful for the financial support of this research, performed in the frame of the Project CEEX 75 AGRAL (2006-2008), by the National Council of Scientific Research in Romania. Also, they thank to the scientists PhD Elena Trotuş and PhD N. Vilău, from the AERDS Secuieni - Neamț District and Caracal - Olt district, respectivelly, for the rape seed samples provided for this research.

\section{REFERENCES}

Agrios G.N. 2005. Plant Pathology, 5th edition, Elsevier Academic Press Amsterdam - Boston - Heidelberg - London - New York - Paris - San Diego - San Francisco - Singapore - Sydney - Tokyo: 450-456; 510-514; 523-526; 534-540; 546-550.

Baicu T., Săvescu A. 1986. Systems of integrated control against crop diseases and pests [in Romanian] Ed. Ceres, Buc.: 264 pp.

Dakowska S., Jędryczka M. 2003. Mycoflora of seeds of spring oilseed rape. 2nd International Seed Health Conference, 16-18 September 2003, Poznań-Poland, Programme \& Abstracts: 32-33.

Hălmăjan V. (ed.). 2006. The guide of the rape producer [in Romanian], Ed. AGRIS, Red. Rev. Agr. Buc.: 203 pp.

Hulea A., Negru Al., Severin V. 1973. Main diseases of seed crops [in Romanian], Intreprinderea Poligrafică Informația, Bucureşti: 245 pp.

Jędryczka M., Nikonorenkov V.A., Levitin M., Gasich E., Lewartowska E., Portenko L. 2002. Spectrum and severity of fungal diseases om spring oilseed rape in Russia, IOBC/wprs Bulletin, 25 (2): 13-20

Jędryczka M., Wang G., West J. 2003. Influence of fungicide treatment of oilseed rape plants on contamination of seed material, 2nd International Seed Health Conference, 16-18th September 2003, Poznań-Poland, Programme \& Abstracts: 44-45

Kirk P., Cannon P.F., Minter D.C., Stalpers J.A. 2008. Dictionary of the Fungi, 10th edition, CABI Publishing, CAB International, Wallingford, Oxon OV10 8De, UK, $771 \mathrm{pp}$.

Machado J.C., Langerak C.J., Jaccoud-Filho D.S. 2002. Seed-borne fungi: A contribution to routine seed health analysis, 1st edition, ISTA, Zürich, Switzerland, 138 pp.

Malone J.P., Muskett A.E. 1997. Seed-borne fungi. Description of 77 fungus species, 3rd edition, ISTA, Zürich, Switzerland: 191 pp.

Neergaard P. 1979. Seed Pathology, Macmillan Press Ltd., London \& Bashingstoke: 538 pp.

Raicu C., Baciu D. 1978. Seed Pathology [in Romanian]. Ed. Ceres, Bucureşti: 207 pp.

Sadowski C., Dakowska S., Łukanowski S., Jędryczka M. 2002a. Occurrence of fungal diseases on spring rape in Poland, IOBC/wprs Bulletin 25 (2): 1-12. 
Sadowski C., Jankowski K., Łukanowsk i S., Trzciński J. 2002b. Health status of spring rape plants and seeds as affected by the sowing date and fertilisation with sulphur, boron and magnesium, IOBC/ wprs Bulletin, 25 (2): 93-102.

Saharadan G.S., Mehta N., Sangwan M.S. 2005 r. Diseases of oil crops, Indus Publishing Co., New Dehli: 15-86.

Şesan T.-E. 2008. Evaluation of fungal diversity of rape seeds in the South of Romania, Book of Abstracts, MP-171, The XIIth International Congress of Mycology - IUMS - Turkey, Istanbul, 5-9th August 2008: 36 .

Şesan T.-E., Groza O. 2007. Mycobiota associated with rape seeds in Romania. Abstracts of the XVth Congress of the European Mycological Association, 16-22nd September 2007, Saint Petersburg, Russia: 264.

Tabuc C., Ştefan G. 2005. Evaluation of fungal and mycotoxicological contamination degree of seeds and groats of soybean, sunflower and rape during 2002-2004 [in Romanian]. The IVth International IBNA Symposium "Farm animals biology and nutrition in the frame of integration in the European research": 55

$* * *$ http://www.indexfungorum.org

* * * 2006. Canola Canada Annual Report 2005-2006, Canola Council of Canada: 1-23

** * 2007-2011. Romanian Statistical Yearbook. 2007: 507-523; 2008: 579-605; 2009: 649-675; 2010: 411437; 2011: 433-459 